of the agricultural industry and the use of this material for price reviow and agricultural policy. In 1949 he was appointed lecturer in agricultural economics at the University of Leeds, a post which ho held until 1953 when he was appointed reader in agricultural oconomics and head of the Department at the University of Manchester. His own research work has been mainly in the field of agricultural policy and on the economies of grassland production and utilization. $\mathrm{He}$ has served on various national and international committees on agricultural problems.

\section{Vulcain Reactor}

IN reply to questions in the House of Commons on December 22, the Joint Under-Secretary of State for Education and Science, Mr. J. Boydon, said that basic engineering and physical work in the research and development programme for the Vulcain reactor was now also complete, and a Vulcain-type core would be loaded in the Belgian oxperimental reactor $B R 3$ in mid-1965 for irradiation to high burn-up. The cost to the Atomic Energy Authority so far was about $£ 1 \cdot 6$ million. The decision to proceed with a prototypo fast-breeder reactor must await the outcome of the present development programme based on the experimental reactor at Dounreay and particularly on the design of the fuel.

\section{The Museum of London Bill}

AT the Committee Stage of the Museurn of London Bill in the House of Lords on December 21 and in answer to questions from Lord Chorley and Lord Airedale regarding the position of staff transferred from Guildhall Museum and the London Museum, Lord Champion confirmed his assurance that there would be no down-grading of staff transferred from either Museum, and added that the Governmont would always be prepared to meet representatives of the staff associations to consider these matters. It was inevitable and natural that the terms and conditions of service of the staff of the new Museum should be nearer to local government than to Civil Service practice. The whole question had already been carefully considered, but final decisions could not be taken until the Bill became law and the Board of Governors was finally appointed. Fair and attractive terms would be offered to the staff and these terms would be maintained fair and attractive. There were at present about 70 staff in the London Museum and only seven in Guildhall Museum. While it was accopted that there must be negotiating machinery, it did not appear appropriate to insert a clause making arrangements for negotiation and arbitration statutory. (See also p. 237 of this issue of Nature.)

\section{Improvement in the Status of Technology}

IN a written answer in the House of Commons on December 23, the Secretary of State for Education and Soienee, Mr. M. Stewart, said that, in accordance with the recommondations of the Interdepartmental Committee on Improvement in the Status of Technology, a working party had been set up under his Department's chairmanship, on which the Departments were represented and the Joint Council of Engineering Institutions had been represented at recent meetings. The working party would rely chiefly on continuing to stimulate the interest of the Press and television, and there were close consultations between the working party and television authorities, who were responding to the need for programmes of technological interest. A programme of special Government publicity, prepared with the aid of the Central Office of Information, would includo films, exhibitions and publications, and an exhibition on the theme of 'Applied Science' would be held at the end of December in conjunction with the annual conference of the Association for Science Education at the Imperial College of
Seience and Technology, South Kensington. The working party was reconsidering the Inter-Departmental Committee's recommendations regarding careers advisers in the schools, the provision of career literature and the promotion of films and broadeasts featuring technological subjects. The Committee's report had been considered by the University Grants Committee, which was taking up with the universities those recommendations that affected them, especially the question of flexibility in courses.

\section{Anglo-Soviet Co-operation in Agricultural Research}

AN agreement was signed in London on January 6 giving effect to arrangements for future co-operation between the United Kingdom and the U.S.S.R, in agricultural research. The agreoment, which runs for five years initially, provides for: (a) exchange of information and, as appropriate, of scientific material and visits betweon scientists and institutions of the two countries on some 61 specified research topics under seven general headings-crop production, soil science, plant protection, livestock production, veterinary science, farm mechanization, and water economy; (b) exchange of scientific delegations in 1965; (c) designated 'co-ordinating centres' in each country; (d) a further moeting of experts in London later in the year, and thereafter annual meetings, to keep the working of the agreement under roview. At the signing ceremony, the Minister of Agriculture, Fisheries and Food, the Rt. Hon. F. Peart, M.P., paid tribute to his predecessor, Mr. Christopher Soames, who promoted the idea. On bohalf of the U.S.S.R., the agreemont was signed by the Soviet Ambassador, His Excellency Alexander Soldatov. Speaking to the Soviet delegation, Mr. Poart said: "Her Majesty's Government welcome the agreement we have just signed as a valuable extension of our friendly relations with your Government. It holds out the promise of really useful co-operation in a field where a glance at the agreement itself shows each of our countries has much to offer the other.... Our scientists and scientific institutions will, I know, be working very hard to gain the maximum benefit, for both countries, from the agreement, and in doing so they will have at all times the strong support of myself and my colleagues".

\section{First Report of the Expert Committee on Drug Toxicity}

IN August 1962 the Association of the British Pharmaceutical Industry set up an 'Expert Committee' to advise on certain aspects of the testing of drugs for toxicity. The terms of reference of the Committee were: (1) To review laboratory testing procedures for the assessment of drug toxicity and make recommendations. (2) To make recommendations for promoting the exchange of, and the prompt utilization of, knowledge and experience in this field. (3) To advise on technical and scientific problems of toxicity testing. The first report of the Expert Committeo on Drug Toxicity covers only the first term of reference, and does this very adequately (Pp. 24. London: Association of the British Pharmaceutical Industry, 1964). It explains the reasoning behind the toxicity studins which should be carried out before a new substance is given to man, and makes recommendations concerning the tests which should be performed. The report is clear and concise and should bo road by everyone who is interested in the toxicity of drugs.

\section{Industrial Behaviour and Personnel Management}

WITH the increasing pace of technological change, it is imperative to make people aware of the need to adapt. It is also necessary to develop specialists in the enalysis of the social and psychological problems which accompany technical and economic change. Prof. 'T. Lupton, Montague Burton professor of industrial relations in the University of Leeds, has put forward his belief in a recent publication from the Institute of Personnel Management that the behavioural sciences are now sufficiently well 